\title{
Mercury exposure of children living in Amazonian villages: influence of geographical location where they lived during prenatal and postnatal development
}

\author{
JOYCE S. FREITAS ${ }^{1}$, ELIZA MARIA C.B. LACERDA ${ }^{3}$, DARIO RODRIGUES JÚNIOR ${ }^{1}$, TEREZA CRISTINA O. \\ CORVELO $^{1,2}$, LUIZ CARLOS L. SILVEIRA ${ }^{1,2,3}$, MARIA DA CONCEIÇÃO N. PINHEIRO ${ }^{1}$ and GIVAGO S. SOUZA ${ }^{1,2^{*}}$ \\ ${ }^{1}$ Núcleo de Medicina Tropical, Universidade Federal do Pará, Avenida Generalíssimo \\ Deodoro, 92, Umarizal, 66055-240 Belém, PA, Brazil \\ ${ }^{2}$ Instituto de Ciências Biológicas, Universidade Federal do Pará, Rua Augusto Correa, 01, Guamá, 66075-110 Belém, PA, Brazil \\ ${ }^{3}$ Universidade do Ceuma, Rua José Montello, 1, Renascença II, 65075-120 São Luís, MA, Brazil \\ Manuscript received on January 29, 2018; accepted for publication on June 18, 2018
}

\begin{abstract}
How to cite: FREITAS JS, LACERDA EMCB, RODRIGUES JÚNIOR D, CORVELO TCO, SILVEIRA LCL, PINHEIRO MCN AND SOUZA GS. 2019. Mercury exposure of children living in Amazonian villages: influence of geographical location where they lived during prenatal and postnatal development. An Acad Bras Cienc 91: e20180097. DOI 10.1590/0001-3765201920180097.
\end{abstract}

\begin{abstract}
Introduction: In some Amazonian river basins, hair mercury concentration is above the recommended levels. We evaluated the influence of birth geographical location in the hair mercury level of Amazonian riverine children. Materials and Methods: Hair mercury concentration was measured in 219 children living in four Amazonian riverine communities: Tapajós River (São Luiz do Tapajós and Barreiras villages, $\mathrm{n}=110$ ), Tocantins River (Limoeiro do Ajurú village, $\mathrm{n}=61$ ), and Caeté River (Caratateua village, $n=48$ ). We used Poisson regression analysis to evaluate the association between native and nonnative children from each village and its hair mercury concentration. Results: Higher mercury exposure was found in native children from São Luiz do Tapajós (range $=0.81-22.38 \mu \mathrm{g} / \mathrm{g}$ ) followed by native children from Barreiras (range $=0.48-13.46 \mu \mathrm{g} / \mathrm{g}$ ), non-native children from São Luiz do Tapajós (range = 0.26-22.18 $\mu \mathrm{g} / \mathrm{g}$ ), non-native children from Barreiras (range $=0.43-20.76 \mu \mathrm{g} / \mathrm{g}$ ), followed by the children from Caeté and Tocantins river basins. We observed that Tapajós villages' native children had higher prevalence of mercury exposure children than other children $(\mathrm{p}<0.05)$. Conclusions: Birth geographical location has association to mercury levels in the hair of children who lived in a same community with history of mercury exposure.
\end{abstract}

Key words: children development, mercury exposure, Tapajós River basin, Tocantins River basin, Caeté River basin.

\section{INTRODUCTION}

In the last decades, mercury exposure in the Brazilian Amazon was investigated by many research groups

Correspondence to: Givago da Silva Souza

E-mail: givagosouza@ufpa.br

ORCid: orcid.org/0000-0002-4525-3971

* Contribution to the centenary of the Brazilian Academy of Sciences.
(Akagi et al. 1995, Malm et al. 1995, Grandjean et al. 1999, Barbosa et al. 1998, Hacon et al. 2000, Santos et al. 2000, Filion et al. 2006, Pinheiro et al. 2006, Passos and Mergler 2008, Dórea et al. 2012). In these works, mercury exposure was quantified by measuring the mercury concentration in the head hair of adults and children. There was a particular concern about mercury exposure of populations 
living in Amazon riverine villages, especially those settled in the basins of the Madeira River and Tapajós River, once they suffered the influence of the high gold-mining activity occurring in these regions (Grandjean et al. 1999, Santos et al. 2000, Pinheiro et al. 2007, Marinho et al. 2014). Along the years, it was showed that these subjects have an amount of mercury in the head hair higher than expected for a non-exposed population to the metal, but lower than the mercury levels found in populations severely affected by environmental accidents such as those that occurred in Minamata, Niigata (Japan) and Iraq.

In the last two decades, the mercury concentration in the head hair of inhabitants of the Tapajós River basin remained above $10 \mu \mathrm{g} / \mathrm{g}$ (Pinheiro et al. 1999, 2000, 2012, Crespo-López et al. 2011, Corvelo et al. 2014). The World Health Organization established that $10 \mu \mathrm{g} / \mathrm{g}$ is a limit of mercury hair concentration to avoid the mercury transfer from the mother to the fetus (WHO-IPCS 1990). Therefore, the mercury levels in Tapajós basin put on risk the prenatal development of children in this region. During postnatal development, these children continue to be exposed to mercury through a diet predominantly based on fish.

Previous studies have shown that children from the Tapajós River basin also had mean mercury hair concentration above $10 \mu \mathrm{g} / \mathrm{g}$ (Grandjean et al. 1999, Pinheiro et al. 2006, Marinho et al. 2014). These studies have not considered the fact that family migrations are common in the Amazon, and many families changed their home from non-exposed areas to exposed areas and vice-versa. These studies used samples that comprised children living in the community in the previous one or two years. There were no reports of the risk of mercury exposure comparing native with non-native populations.

The present study compared mercury concentration in the hair of children living in riverside villages from the Tapajós River basin considering the geographical location of the prenatal development. Similar comparisons were performed for children from other places of the Amazon in the Tocantins River basin and Caeté River basin, which have different environmental conditions. The Tocantins River basin also has been monitored during the last years and it is considered an area of low mercury exposure, while the Caeté River basin is located in the Atlantic Ocean coast area and it was never monitored for mercury exposure.

\section{MATERIALS AND METHODS}

\section{SUBJECTS}

The children who participated in this study were given birth from women aged from 25 to 40 years old. Figure 1 shows a map of the State of Pará, Brazil, with the location of the villages where these children lived: Caratateua, located on the Atlantic Ocean coast, in the Caeté River basin, with no reports of mercury exposure; Limoeiro do Ajurú, located in the Tocantins River basin, with no records of gold-mining activity and reported as having low mercury exposure; Barreiras and São Luiz do Tapajós, both of them located in the Tapajós River basin, that have been extensively monitored as suffering substantial mercury exposure (Bidone et al. 1997, Dolbec et al. 2000, Barbieri and Gardon 2009, Khoury et al. 2013). These communities were small riverside villages located on the main river. All villages had the same socio-demographical profile of poor people with low sanitary conditions, high incidence of infectious diseases, parasitosis, and low education level. The men living in the communities usually worked on fishing, and the women worked at home taking care of children. No parents had activity in the gold-mining industry. The fish was the main food source for the communities, and the only determinant of mercury level in the head hair was the amount of fish consumption.

Children aging from 7 to 14 years old were selected by direct invitation to the parents or caregivers $(n=219)$. They were recruited as 


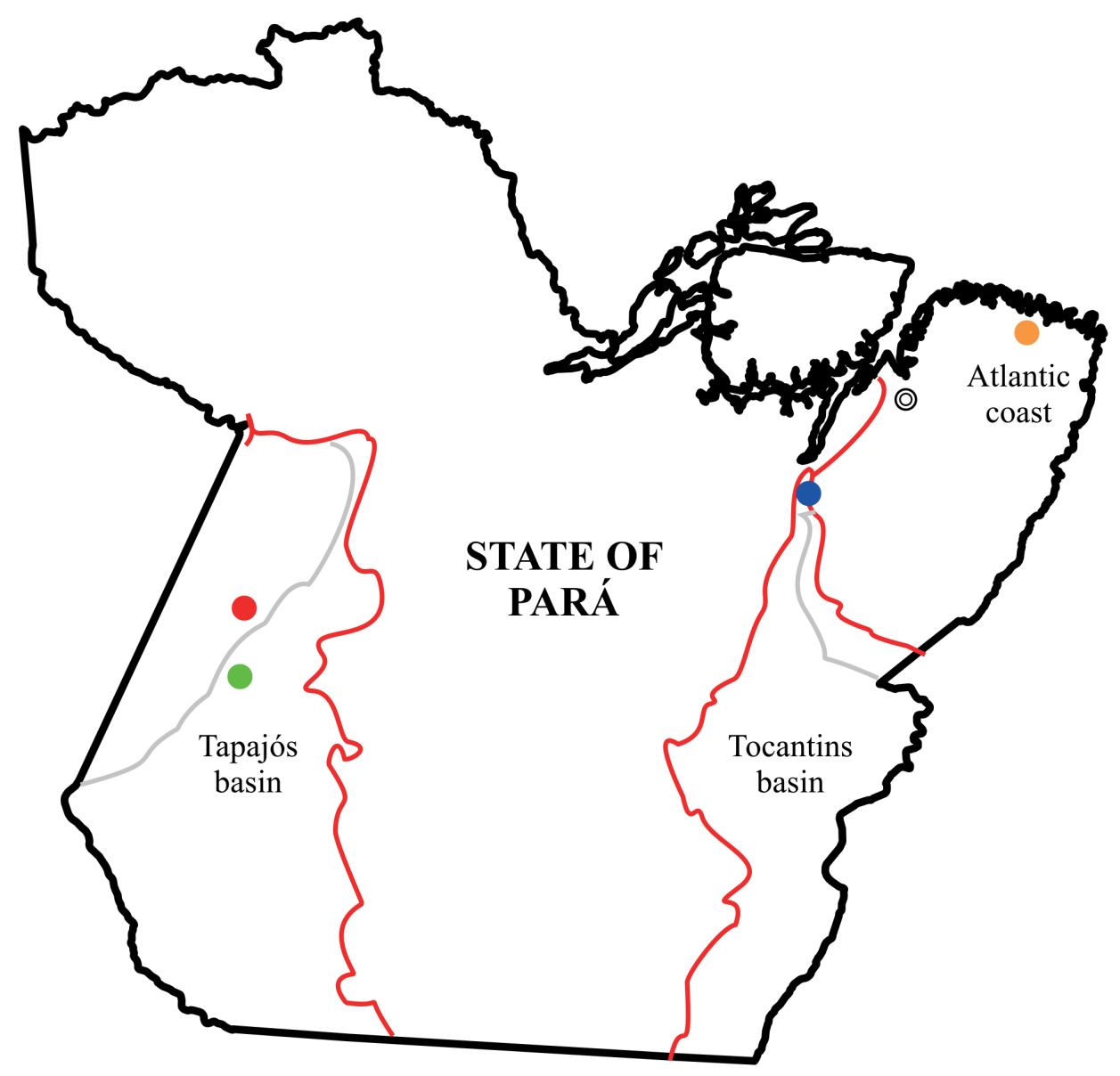

Barreiras $\left(4^{\circ} 4^{\prime} 50^{\prime \prime} \mathrm{S}, 55^{\circ} 41^{\prime} 40^{\prime \prime} \mathrm{W}\right)$

São Luiz do Tapajós ( $4^{\circ} 26^{\prime} 52^{\prime \prime}$ S, $\left.56^{\circ} 14^{\prime} 38^{\prime \prime} \mathrm{W}\right)$

Limoeiro do Ajuru ( $\left.1^{\circ} 53^{\prime} 56^{\prime \prime} \mathrm{S}, 49^{\circ} 23^{\prime} 27^{\prime \prime} \mathrm{W}\right)$

Caratateua $\left(0^{\circ} 59^{\prime} 43^{\prime \prime} \mathrm{S}, 46^{\circ} 43^{\prime} 21^{\prime \prime} \mathrm{W}\right)$

(○) Belém $\left(1^{\circ} 27^{\prime} 21^{\prime \prime} \mathrm{S}, 48^{\circ} 30^{\prime} 14^{\prime \prime} \mathrm{W}\right)$

Figure 1 - Map of the State of Pará showing the locations studied in this work. The red circle represents the community of Barreiras, situated on the left bank of the Tapajós River. The green circle represents the community of São Luiz do Tapajós, situated on the right bank of the Tapajós River. The blue circle represents the community of Limoeiro do Ajuru, located in the Tocantins River basin and the orange circle represents the community of Caratateua, located in the Caeté River basin, near the Atlantic Coast of the Pará State. Belém is the town of the Pará State. 
follows: Caratateua, 48 children, 25 females and 23 males, $10.43 \pm 1.95$ years old; Limoeiro do Ajurú, 61 children, 35 females and 26 males, 10.85 \pm 2.12 years old; Barreiras, 70 children, 40 females and 30 males, $11.27 \pm 2.13$ years old; and São Luiz do Tapajós, 40 children, 19 females and 21 males, $10.13 \pm 1.97$ years old. Recruited children represented about $40 \%$ of the total of children living in each village.

Information about the natural history of each child was collected from parents or caregivers, who gave written consent for child participation in the present study. All procedures used in this work were approved by the Ethical Committee for Research with Humans of the Tropical Medicine Nucleus, Federal University of Pará, Brazil (Report \#392.245), and followed the tenets of the World Medical Association Declaration of Helsinki Ethical Principles for Medical Research Involving Human Subjects.

MEASUREMENT OF TOTAL MERCURY CONCENTRATION IN HAIR SAMPLES

Total mercury concentration in the children's hair was measured by using cold vapor atomic absorption spectrometry according to the method of Akagi et al. (2004). Measurements were performed in the Laboratory of Environmental and Human Toxicology, Tropical Medicine Nucleus, Federal University of Pará, using an SP-3D Mercury Analyzer (Nippon Corporation, Tokyo, Japan). The procedure follows the international standards for analytical quality assessment using the International Atomic Energy Agency 086 reference material. The limit of detection was 0.1 ppb. Hair samples were obtained from the scalp of the occipital region. Hair samples were washed with acetone to remove external contamination and then cut into small pieces using stainless-steel scissors. The samples were accurately weighed in an analytical balance (Shimatzu, Kyoto, Japan) and then transferred to the mercury analyzer to quantify their total mercury concentration.

\section{DATA ANALYSIS: COMPARISON OF MERCURY} HAIR CONCENTRATION AMONG THE VILLAGES

Data on mercury concentration were divided into eight subgroups: native children and non-native children of Limoeiro do Ajuru; native and nonnative children of Caratateua; native and nonnative children of Barreiras; native and non-native children of São Luiz do Tapajós. The database for each group was analyzed using descriptive statistics (median, first quartile, third quartile, maximum, minimum) and the variance of the sample compared using Kruskall-Wallis test followed by Dunn posthoc test $(\alpha=0.05)$.

We applied a Poisson regression analysis to estimate the prevalence ratio of children with hair mercury concentration equal or above 2 microgram/g among the different communities.

\section{RESULTS}

For each community, two groups of children were identified: native children, those who had prenatal development in the community where they were living; and non-native children, those that came from locations different from the community where they were living. Non-native children were living for at least one year in the community where they were studied. There were no significant differences of age between the groups ( $p>0.05)$ : native children from Limoeiro do Ajuru, $11 \pm 1.96$ years old; nonnative children from Limoeiro do Ajuru, $11 \pm$ 2.87 years old; native children from Caratateua, $10 \pm 1.89$ years old; non-native children from Caratateua $10.5 \pm 2.27$ years old; native children from Barreiras, $12 \pm 2.14$ years old; non-native children from Barreiras, $11 \pm 2.15$ years old; native children from São Luiz do Tapajós, $10 \pm 1.99$ years old; non-native children from São Luiz do Tapajós, $11 \pm 1.98$ years old. The descriptive statistics of 
TABLE I

Mercury hair concentration from native and non-native children from riverine communities of different river basins in Brazilian Amazon.

\begin{tabular}{|c|c|c|c|c|}
\hline \multirow[b]{2}{*}{ Groups } & \multicolumn{4}{|c|}{ Mercury hair concentration $(\mu \mathrm{g} / \mathrm{g})$} \\
\hline & $\mathbf{N}$ & Median & Maximum & Minimum \\
\hline \multicolumn{5}{|c|}{ Limoeiro do Ajuru (Tocantins River basin) } \\
\hline Native & 54 & 0.4 & 1.91 & 0.03 \\
\hline Non-native & 9 & 0.5 & 1.26 & 0.06 \\
\hline \multicolumn{5}{|c|}{ Caratateua (Caeté River basin) } \\
\hline Native & 38 & 1.28 & 8.15 & 0.06 \\
\hline Non-native & 10 & 1.3 & 3.3 & 0.51 \\
\hline \multicolumn{5}{|c|}{ Barreiras (Tapajós River basin) } \\
\hline Native & 43 & 2.54 & 13.46 & 0.48 \\
\hline Non-native & 27 & 2.02 & 20.76 & 0.43 \\
\hline \multicolumn{5}{|c|}{ São Luiz do Tapajós (Tapajós River basin) } \\
\hline Native & 24 & 5.79 & 22.38 & 0.81 \\
\hline Non-native & 16 & 2.51 & 22.18 & 0.26 \\
\hline
\end{tabular}

mercury hair concentration for each group is shown in Table I.

In general, children from the Tapajós river basin (Barreiras and São Luiz do Tapajós) had higher mercury hair concentration than children from other regions. Considering the location of prenatal development, native children from São Luiz do Tapajós had a higher median value of mercury hair concentration than the other seven groups $($ median $=5.79 \mu \mathrm{g} / \mathrm{g}$, range $=0.81-22.38$ $\mu \mathrm{g} / \mathrm{g})$. They were followed by native children from Barreiras (median $=2.54 \mu \mathrm{g} / \mathrm{g}$, range $=0.48$ $13.46 \mu \mathrm{g} / \mathrm{g}$ ); non-native children from São Luiz do Tapajós $($ median $=2.51 \mu \mathrm{g} / \mathrm{g}$, range $=0.26-22.18$ $\mu \mathrm{g} / \mathrm{g}$ ); non-native children from Barreiras (median $=2.02 \mu \mathrm{g} / \mathrm{g}$, range $=0.43-20.76 \mu \mathrm{g} / \mathrm{g}$ ); non-native children from Caratateua (median $=1.3 \mu \mathrm{g} / \mathrm{g}$, range $=0.51-3.46 \mu \mathrm{g} / \mathrm{g}$ ); native children from Caratateua ( median $=1.28 \mu \mathrm{g} / \mathrm{g}$, range $=0.06-8.15 \mu \mathrm{g} / \mathrm{g}$ ); nonnative children from Limoeiro do Ajurú (median $=0.5 \mu \mathrm{g} / \mathrm{g}$, range $=0.06-1.26 \mu \mathrm{g} / \mathrm{g}$ ); and native children from Limoeiro do Ajurú (median $=0.4$ $\mu \mathrm{g} / \mathrm{g}$, range $=0.03-1.91 \mu \mathrm{g} / \mathrm{g}$ ).

Only children from villages of the Tapajós River basin showed a significant difference between mercury hair concentration in natives and non-natives $(\mathrm{p}<0.05)$ : native children from São Luiz do Tapajós and Barreiras had mercury hair concentration significantly higher than nonnative children from the same communities. The community from Tocantins river and Caeté river, no difference was found between native and nonnative children $(p>0.05)$.

We observed that the equation that described the Poisson regression for our data was:

$$
\begin{aligned}
& { }_{i}=e^{-0.15} \times e^{1.33 \times N B} \times e^{1.37 \times N N B} \times e^{2.25 \times N S L T} \times e^{1.59 \times N N S L T} \times \\
& e^{0.64 \times N C} \times e^{0.68 \times N N C} \times e^{-0.73 \times N L A} \times e^{-0.28 \times N N L A}
\end{aligned}
$$

Where is the predicted value of subjects with exposure above 2 microgram/g. NB, NNB, NSLT, NNSLT, NC, NNC, NLA and NNLA represent the number of native $(\mathrm{N})$ or non-native $(\mathrm{NN})$ subjects from Barreiras (B) or São Luís do Tapajós (SLT) or Caratateua (C) or Limoeiro do Ajurá (LA) with mercury exposure above above 2 microgram/g.

Table II shows the prevalence ratios among the different groups of children. We found positive rates for Tapajós region (São Luís do Tapajós and Barreiras villages) and Caeté region (Caratateua village), as well as we found negative rates for 
TABLE II

Prevalence ratios among the different groups of children (column/row).

\begin{tabular}{cccccccccc}
\hline & NB & NNB & NSLT & NNSLT & NC & NNC & NLA & NNLA \\
\hline NB & & 1.033 & 1.69 & 1.19 & 0.48 & 0.51 & -0.55 & -0.21 \\
NNB & 0.97 & & 1.64 & 1.16 & 0.47 & 0.49 & -0.53 & -0.2 \\
NSLT & 0.59 & 0.61 & & 0.71 & 0.28 & 0.3 & -0.32 & -0.12 \\
NNSLT & 0.84 & 0.86 & 1.42 & & 0.41 & 0.43 & -0.46 & -0.17 \\
NC & 2.08 & 2.14 & 3.52 & 2.49 & & 1.06 & -1.14 & -0.43 \\
NNC & 1.97 & 2.02 & 3.33 & 2.35 & 0.95 & & -1.08 & -0.41 \\
NLA & -1.83 & -1.88 & -3.1 & -2.18 & -0.88 & -0.93 & & 0.38 \\
NNLA & -4.82 & -4.96 & -8.16 & -5.76 & -2.32 & -2.45 & 2.63 & \\
\hline
\end{tabular}

NB, native children from Barreiras community; NNB, non-native children from Barreiras community; NSLT, native children from São Luiz do Tapajós community; NNSLT, native children from São Luiz do Tapajós community; NC, native children from Caratateua community; NNC, non-native children from Caratateua community; NLA, native children from Limoeiro do Ajuru community; NNLA, non-native children from Limoeiro do Ajuru community.

the population from Tocantins region (Limoeiro do Ajuru village). We observed that the higher prevalence ratios were found between communities from Tapajós river and Tocantins river.

\section{DISCUSSION}

Children are more vulnerable to mercury exposure than adults because of their developing nervous system and immature metabolic pathways (BoseO'Reilly 2010). Many studies have described that even children with low to moderate mercury concentrationin the hair show significant impairment in behavioral, sensory, and motor tasks, but all of them without clinical complaints (Grandjean et al. 1998, 1999, Marinho et al. 2014, WHO 2010). In the Amazon, until today there were no formal reports of clinical complaint by children or adults that could be associated with mercury exposure by eating contaminated fish. Some investigations reported findings of sensorial and motor deficits in these populations suggesting subclinical functional changes due to mercury exposure (Silveira et al. 2003, Rodrigues et al. 2007, Freitas et al. 2015). It must be considered that all children studied in this work had no clinical complaint that could be related to mercury exposure, but a continuous mercury exposure for a longer time could bring health problems.

We found that only for children living in the Tapajós River basin, the location of the pre-natal development influenced the current mercury hair levels. The native children from these communities had higher mercury hair concentration than nonnative children. The main difference between the Tapajós River villages and the other communities is the history of high mercury exposure due to the gold-mining activity that occurred in the Tapajós River basin since the 1970's. Mercury exposure occurred through the diet rich in contaminated fish. It is unlikely that other confounders must be playing a role once all the communities have the same social-demographic profile. The villages had no direct contact with the gold-mining area or industry that worked with mercury. All the villages had the fish consumption as the basis of the animal protein intake.

Several studies have monitored the mercury exposure of children living in the Brazilian Amazon. Grandjean et al. (1999) investigated the mercury exposure of 7-12 years old children living in the Tapajós River basin. They found that hair mercury concentration was dependent on the community location along the river: the closer the community 
was from the gold-mining region, the higher the mercury hair concentration. They observed that São Luiz do Tapajós was the community with higher mercury concentration, $25.4 \mu \mathrm{g} / \mathrm{g}$, ranging from 0.6 to $83.5 \mu \mathrm{g} / \mathrm{g}$ and higher prevalence of cases with mercury exposure above 2 microgram/g. Santos et al. (2000) studied the mercury concentration in the hair of subjects of different ages living in the Tapajós. They observed that the mercury concentration increased as a function of age reaching a peak in 15 years old subjects. Pinheiro et al. (2007) also measured the mercury concentration in the hair of a population ranging from newborns to 12 years old children in two communities of the Tapajós River basin, Barreiras and São Luiz do Tapajós, and one community from the Tocantins River basin, Panacauera. In all communities, the higher was the age, the higher was the mercury concentration, indicating a cumulative effect of mercury exposure. Again, the communities located in the Tapajós River basin had the highest mercury exposure, and the children from São Luiz do Tapajós had higher mean mercury concentration than those from Barreiras. All the authors agreed that the higher levels in the Tapajós River basin are mainly due to the mercury pollution of the river originated from gold mining activity, leading to mercury bioaccumulation in the food chain and reaching the human population by fish consumption.

Interestingly, the hypothesis of higher mercury accumulation in native children is not applicable to the results obtained from mercury exposure in the communities of the Tocantins River basin and Caeté River basin. In both locations, there were no differences between mercury concentration in native and non-native children. There were no reports about mercury concentration in the hair of populations living on the Atlantic Coast of the Pará State, and there was no gold-mining activity or any other industry close to this area. Probably the source of mercury is the soil, and further studies of chemical analysis of the soil are necessary to confirm this assumption. Other ocean coast places around the world were identified with low-to-intermediate mercury concentrations (Hajeb et al. 2008, Kim et al. 2013). The origin of mercury in coastal waters depends on sedimentation of mercury bound particles from the open sea and atmosphere (Cossa et al. 1986). Limoeiro do Ajurú was confirmed as a community not exposed to mercury similarly to the other communities from the lower Tocantins River basin that were previously investigated (Pinheiro et al. 2006, 2007).

The level of mercury exposure in the Tapajós River basin was intermediate between the high levels that led to neurological disorders and deaths in Minamata and other severely affected areas around the World and levels observed in areas with low seafood or fish consumption. The current mercury concentrations in head hair were not associated with clinical symptoms. The knowledge of risk factors such as the location of prenatal development could help to guide policies of public health towards riverine populations from the Tapajós River basin. For children populations from the Tocantins and Caeté basins, the current mercury exposure seems to be safe for their health.

\section{CONCLUSIONS}

Children who were born and lived in riverine villages with a history of high mercury concentration had higher levels of mercury in the hair than children who lived in the same community but were not born in this community. For villages with a history of low mercury exposure, there were no differences between mercury exposure of native and nonnative children. The levels of mercury exposure in the Tapajós River basin is intermediate between the high levels that led to neurological disorders and deaths in locations such as Minamata and Niigata, and levels from areas with low seafood or fish consumption. The current mercury hair levels were associated with clinical complaints. 
The knowledge of risk factors such as the location of prenatal development could guide policies of public health towards these riverine populations.

\section{ACKNOWLEDGMENTS}

This research was supported by the following grants: CAPES Pro-Amazônia; Conselho Nacional de Desenvolvimento Científico e Tecnológico (CNPq \#442191/2014-6), \#43178/2016-0. JSF and DRS received Coordenação de Aperfeiçoamento de Pessoal de Nível Superior (CAPES) fellowships for graduate students. EMCBL received a CAPES Pro-Amazônia postdoctoral fellowship. LCLS and MCNP are CNPq research fellows. We wish to thank the inhabitants of Amazonian villages that accepted to participate of this study.

\section{AUTHOR CONTRIBUTIONS}

JSF collected data. GSS prepared the manuscript. EMCBL conducted the statistical analysis. DRJ analyzed the samples of mercury. TCOC participated in the design of the study. LCLS revised the manuscript. MSNP participated in its design and coordination and helped to draft the manuscript and revision of the manuscript. All authors read and approved the final manuscript.

\section{REFERENCES}

AKAGI H, MALM O, KINJO Y, HARADA M, BRANCHES FPJ, PFEIFFER WC AND KATO H. 1995. Methylmercury pollution in Amazon, Brazil. Sci Total Environ 175: 85-95.

BARBIERI FL AND GARDON J. 2009. Hair mercury levels in Amazonian populations: spatial distribution and trends. Int J Health Geogr 71: 1-20.

BARBOSA AC, SILVA SR AND DOREA JG. 1998. Concentration of mercury in hair of indigenous mothers and infants from the Amazon basin. Arch Environ Contam Toxicol 34: 100-105.

BIDONE ED, CASTILHOS Z, SOUZA CTM AND LACERDA LD. 1997. Fish contamination and human exposure to mercury in the Tapajós river basin, Pará State, Amazon, Brazil: a screening approach. Bull Environ Contam Toxicol 59: 194-201.
BOSE-O'REILLY S, MCCARTY KM, STECKLING N AND LETTMEIER B. 2010. Mercury exposure and children's health. Curr Probl Pediatr Adolesc Health Care 40: 186215.

CORVELO TCO, OLIVEIRA EAF, PARIJÓS AM, OLIVEIRA CSB, SOCORRO PLR, ARAÚJO AA, COSTA CA, SILVEIRA LCL AND PINHEIRO MCN. 2014. Monitoring mercury exposure in reproductive aged women inhabiting the Tapajós river basin, Amazon. Bull Environ Contam Toxicol 92: 1469-1482.

COSSA D, COQUERY M, GOBEIL C AND MARTIN JM. 1986. Mercury fluxes at the ocean margins. In: Baeyens W, Ebinghaus R and Vasiliev O (Eds), Global and regional mercury cycles: sources, fluxes and mass balances. NATO ASI Series, Vol. 2. Kluwer Academic Publishers, p. 229247.

CRESPO-LÓPEZ ME, MACÊDO GL, ARRIFANO GPF, PINHEIRO MCN AND HERCULANO AM. 2011. Genotoxicity of mercury: contributing for the analysis of Amazonian populations. Environ Int 37: 136-141.

DOLBEC J, MERGLER D, SOUSA PASSOS CJ, SOUSA DE MORAIS S AND LEBEL J. 2000. Methylmercury exposure affects motor performance of a riverine population of the Tapajós river, Brazilian Amazon. Int Arch Occup Environ Healt 73: 195-203.

DÓREA JG, MARQUES RC AND ISEJIMA C. 2012. Neurodevelopment of Amazonian infants: antenatal and postnatal exposure to methyl- and ethylmercury. J Biomed Biotechnol ID 132876.

FILLION M, MERGLER D, PASSOS CJ, LARRIBE F, LEMIRE M AND GUIMARAES JR. 2006. A preliminary study of mercury exposure and blood pressure in the Brazilian Amazon. Environ Health 5: 1-9.

FREITAS JD, LACERDA EMCB, RODRIGUES JÚNIOR D, BONCI DMO, CÔRTES MIT, CORVELO TCO, VENTURA DF, SILVEIRA LCL, PINHEIRO MCN AND SOUZA GS. 2015. Effects of mercury exposure on the visual functions of children from Amazonian riverine villages. ARVO Annual Meeting. Inv Ophthalmol Vis Sci 56:E-Abstract 523/A0255.

GRANDJEAN P, WEIHE P, WHITE RF AND DEBES F. 1998. Cognitive performance of children prenatally exposed to "safe" levels of methylmercury. Environ Res 77: 165-172.

GRANDJEAN P, WHITE R, NIELSEN A, CLEARY D AND OLIVEIRA SANTOS EC. 1999. Methylmercury neurotoxicity in Amazonian children downstream from gold mining. Environ Health Perspec 107: 587-591.

HACON S, YOKOO E, VALENTE J, CAMPOS RC, SILVA VA AND MENEZES ACC. 2000. Exposure to mercury in pregnant women from Alta Floresta-Amazon Basin, Brazil. Environ Res 84: 204-210.

HAJEB P, SELAMAT J, ISMAIL A, BAKAR FA, BAKAR J AND LIOE HN. 2008. Hair mercury level of coastal 
communities in Malaysia: a linkage with fish consumption. Eur Food Res Technol 227: 1349-1355.

KHOURY ED, SOUZA GS, SILVEIRA LC, COSTA CA, ARAÚJO AA AND PINHEIRO MC. 2013. Manifestações neurológicas em ribeirinhos de áreas expostas ao mercúrio na Amazônia brasileira. Cad Saúde Pública 29: 2307-2318.

KIM RB, KIM BG, KIM Y, HONG YS, YOU CH AND KIM DS. 2013. Association between low-level mercury exposure and neurobehavioral functions in Korean adults living in a coastal city. Environ Health Toxicol 28: 1-8.

MALM O, BRANCHES FJ, AKAGI H, CASTRO MB, PFEIFFER WC, HARADA M, BASTOS WR AND KATO H. 1995. Mercury and methylmercury in fish and human hair from the Tapajós river basin. Braz Sci Total Environ 175: 141-150.

MARINHO JS, LIMA MO, OLIVEIRA SANTOS EC, JESUS IM, PINHEIRO MCN, ALVES CN AND MULLER RCS. 2014. Mercury speciation in hair of children in three communities of the Amazon. Braz BioMed Res Int 1-10.

PASSOS CJ AND MERGLER D. 2008. Human mercury exposure and adverse health effects in the Amazon: a review. Cad Saúde Pública 24: 503-520.

PINHEIRO MC ET AL. 2006. Comparative study of human exposure to mercury in riverside communities in the Amazon region. Braz J Med Biol Res 39: 411-414.

PINHEIRO MC ET AL. 2007. Mercury pollution and childhood in Amazon riverside villages. Environ Int 33: 56-61.

PINHEIRO MCN, FARRIPAS SSM, OIKAWA T, ARAÚJO CC, AMORAS WW, VIEIRA JLF, SILVEIRAAJA, LIMA ACM, SOUZA GS AND SILVEIRA LCL. 2012. Temporal evolution of exposure to mercury in riverside communities in the Tapajós Basin, from 1994 to 2010. Bull Environ Contam Toxicol. 89: 119-124.
PINHEIRO MCN, GUIMARÃES GA AND NAKANISHI J. 1999. Avaliação da contaminação. mercurial através da análise do teor de $\mathrm{Hg}$ total em amostras de cabelo em comunidades de pescadores da Região do Tapajós / Pará / Brasil. Rev Soc Bras Med Trop 33: 181-184.

PINHEIRO MCN, NAKANISHI J, OIKAWAT, GUIMARÃES GA, QUARESMA M, CARDOSO BS, AMORAS WW, HARADA M, MAGNO C AND VIEIRA JLF. 2000. Exposição humana ao metilmercúrio em comunidades ribeirinhas da região do Tapajós, Pará, Brasil. Rev Soc Bras Med Trop 33: 265-269.

RODRIGUES AR ET AL. 2007. Mercury toxicity in the Amazon: contrast sensitivity and color discrimination of subjects exposed to mercury. Braz J Med Biol Res 40: 415424.

SANTOS ECO, JESUS IM, BRABO ES, LOUREIRI ECB, MASCARENHAS AFS, WEIRICH J, CÂMARA VM AND CLEARY D. 2000. Mercury exposure in riverside Amazon communities in Pará, Brazil. Environ Res 84: 100-107.

SILVEIRA LCL, DAMIN ETB, PINHEIRO MCN, RODRIGUES AR, MOURA ALA, CÔRTES MIT AND MELLO GA. 2003. Visual dysfunction following mercury exposure by breathing mercury vapour or by eating mercury-contaminated food. In: Mollon JD, Pokorny J and Knoblauch K (Eds), Normal and defective colour vision. Oxford: Oxford University Press, p. 407-417.

WHO. 2010. Children's Exposure to Mercury Compounds. World Health Organization (WHO), Geneva.

WHO-IPCS. 1990. Environmental health criteria 101 Methylmercury. World Health Organization (WHO), Geneva. 